\title{
Health research funding and its output in Pakistan
}

Muhammad Arif Nadeem Saqib ${ }^{1,2}$ and Ibrar Rafique ${ }^{1}$

${ }^{1}$ Pakistan Health Research Council, Islamabad, Pakistan. ${ }^{2}$ Associate Professor, National Skills University, Islamabad, Pakistan. (Correspondence to: Ibrar Rafique: ibrarpmrc@gmail.com).

\begin{abstract}
Background: Health research is very important for formulating evidence-based policies.

Aims: To assess the health research funding and its output in the last 5 fiscal years (2013/14 to 2018) in Pakistan.

Methods: Information about health research funding was retrieved from 3 major local agencies, the Higher Education Commission, the Pakistan Science Foundation and the Pakistan Health Research Council. Details of funding from international donors were retrieved and the number of publications was estimated from Pubmed and Pakmedinet.

Results: A total of 1261.6 million Pakistan rupees (Rs) (US\$ 8.4 million) was spent on health research in the last 5 fiscal years, the majority from local donors $(P<0.02)$. Overall funding increased from Rs 104.7 million in $2013-2014$ to Rs 349.8 million 2017-2018. In publications data, 24796 original articles were published, including 16137 Medline and 8659 non-Medline indexed. Overall there was a gradual increase in the number of publications per year, statistically significant for Medline indexed journals. Research funding had a strong correlation (Cronbach $\alpha=0.88$ ) with publications.

Conclusion: Health research funding directly affects health research output. The funding on health research should be considered an investment rather than expenditure.

Keywords: health research, funding, investment, Pakistan

Citation: Saqib MAN; Rafique I. Health research funding and its output in Pakistan. East Mediterr Health J. 2021;27(9):906-910. https://doi.org/10.26719/ emhj.21.038

Received: 02/11/20; accepted: 01/03/21

Copyright $@$ C World Health Organization (WHO) 2021. Open Access. Some rights reserved. This work is available under the CC BY-NC-SA 3.o IGO license (https://creativecommons.org/licenses/by-nc-sa/3.o/igo).
\end{abstract}

\section{Introduction}

Health research is of paramount importance and plays a pivotal role in the improvement of existing health systems, framing evidence-based health care policy, and in generating new initiatives and advancing knowledge about problems relating to public health and their solutions $(1,2)$. It has an important role in identifying the economic and social determinants of health, and ultimately forms the basis for improvement in health programmes and policies (3). This is beneficial to a country in many ways ranging from reducing the direct cost of disease to the development of techniques/products for treatment of disease, and is recognised as an important aspect of economic development and an evidence-based, informed approach to population health $(1,2,4,5)$.

It is imperative for developing countries to recognise the importance of health research and gain momentum in this field $(4,5)$. According to the World Health Organization (WHO), in low- and middle-income countries health research must address local needs, and the evidence generated should be incorporated into policy $(1,2)$. However, the WHO Global Observatory on Health Research and Development showed that there are 73 times more health researchers in the high-income countries than in low-income countries (6). A quarter of the world's population is living in South Asia, where health infrastructure is weak. Due to low investment, there is a dearth of health research in South Asia to determine the gaps between disease and health delivery systems (7). It has been reported that researchers from South Asia contribute only $1.2 \%$ to the annual research.

As in many other countries of the Region, the health research situation in Pakistan is not satisfactory (8). Pakistan has only 25 full time equivalent public health researchers per million population (6). The poor status of health research in Pakistan is due to lack of a research culture, lack of demand for research, low capacity, unavailability of funds and improper dissemination (9). This study describes the spending on health research in Pakistan in the last 5 fiscal years and its impact on research output.

\section{Methods}

We collected information about the spending on health research during the last 5 fiscal years, July 2013-June 2018, from 3 major Pakistani funding agencies, Pakistan Health Research Council, Islamabad, Pakistan Science Foundation, Islamabad, and the Higher Education Commission, Pakistan. For the Pakistan Health Research Council the information was retrieved from the records of the Research, Development and Coordination section using a pre-designed proforma. Letters were sent to the Higher Education Commission and the Pakistan Science Foundation asking them to provide the required information. Letters were also sent to about 63 health research institutions in the country asking them to provide de- 
tails of funding other than the Pakistan Health Research Council, the Higher Education Commission and the Pakistan Science Foundation. Besides this, information about international funding was retrieved from the National Bioethics Committee Pakistan, which gives ethical clearance to internationally funded projects in Pakistan (10).

The research output, i.e. number of publications in local and international journals, was collected from Pakmedinet (http://www.pakmedinet.com/) and PubMed (https://www.ncbi.nlm.nih.gov/pubmed). For PubMed, an advance search was conducted with medical subject headings (MeSH) (www.ncbi.nlm.nih.gov/pubmed) as described earlier (11). In the MeSH tree, the major topic includes all the communicable and noncommunicable diseases and health disciplines. We used the following pattern of search terms:

- MeSH major topic (list of communicable and noncommunicable diseases, list of all medical and health disciplines separated by word OR),

- AND,

- affiliation Pakistan,

- publication date (year)

Pakmedinet was developed in 2001 and indexed about 85 health journals published in Pakistan. The list of all these journals was retrieved along with their publications and filtered for consistency, i.e. regular publication in the last 5 years. About 40 journals had regular issues, therefore their publications were counted on a yearly basis. All other local journals which did not meet the criteria of regularly publication or indexing in Pubmed were excluded.

All data were entered into MS Excel and analysed using SPSS, version 20. Pearson correlation was used to assess the correlation between funding and publication. $P$-value $<0.05$ was considered statistically significant.

\section{Results}

A total of 1261.6 million Pakistan rupees (Rs) (US\$ 8.4 million) was spent on health research during the last 5 fiscal years, 2013-14 to 2017-18. The spending made by the Pakistan Health Research Council, the Pakistan Sci- ence Foundation and the Higher Education Commission along with the international donors is detailed in Table 1. The mean annual spending was Rs 252 (standard deviation 157) million (US\$ 1.68 million). Overall a statistically significant increase was observed for funding with an increasing pattern for local funding, Rs 104.7 million in $2013-14$ to Rs 349.8 million in $2017-18$ ( $P<0.02)$. However, the pattern for international funding was inconsistent (Figure 1). A sharp increase in health research spending was seen in 2015-16 whereas there was only a gradual increase in number of publications during that period (Figure 2).

Overall, 24796 original research articles were published during 2013-2018. Of these, 16137 were in Medline indexed and 8659 in non-Medline indexed (local) journals. The overall number of publications annually per 100000 population was 2.3, while publication in Medline indexed journals was 1.52 per 100000 population annually. A gradual increase was seen in the number of publications over the years. This trend was significantly greater in Medline indexed journals compared with local non-Medline indexed journals (Figure 2$)(P<0.04)$.

The comparison of funding with the number of publications showed a strong correlation, Cronbach $\alpha$ 0.88 indicating that increasing funding had a positive impact on the research output. However, the correlation between funding and pattern of publication, i.e. Medline indexed and non-Medline indexed, was not statistically significant.

\section{Discussion}

Our findings showed that health research output, i.e. number of publications, was directly associated with adequate resources. It has been reported that increasing expenditure on health has a direct effect on increasing publications (12). Health research is important for any country to identify health-related problems and gaps for improvement, and provides evidence-based information to the policy-makers to frame health policies. It is equally important for all countries, however, it attains greater significance in the developing and resource-poor countries. It has been reported that health research in South Asia is scarce and has little role at policy level (13).

\begin{tabular}{|c|c|c|c|c|c|c|}
\hline \multirow[t]{3}{*}{ Year } & \multicolumn{6}{|c|}{ Spending (million Pakistan rupees) } \\
\hline & \multicolumn{4}{|c|}{ Local } & \multirow[t]{2}{*}{ International } & \multirow[t]{2}{*}{ Total } \\
\hline & $\begin{array}{l}\text { Higher Education } \\
\text { Commission }\end{array}$ & $\begin{array}{l}\text { Pakistan Science } \\
\text { Foundation }\end{array}$ & $\begin{array}{l}\text { Pakistan Health } \\
\text { Research Council }\end{array}$ & Institutional & & \\
\hline 2013-14 & 7.43 & 1.23 & 4.10 & 4.08 & 87.86 & 104.7 \\
\hline 2014-15 & 8.21 & 2.69 & 2.62 & 51.11 & 8.50 & 73.13 \\
\hline 2015-16 & 129.45 & 6.53 & 10.2 & 57.15 & 95.42 & 298.75 \\
\hline 2016-17 & 241.88 & 8.83 & 14.77 & 71.82 & 97.89 & 435.19 \\
\hline 2017-18 & 259.86 & 4.03 & 2.85 & 64.28 & 18.81 & 349.83 \\
\hline Total & 646.83 & 23.31 & 34.54 & 248.44 & 308.48 & 1261.6 \\
\hline
\end{tabular}




\section{Figure 1 Spending [Pakistan rupees (Rs)] on health research during 2013-2018}

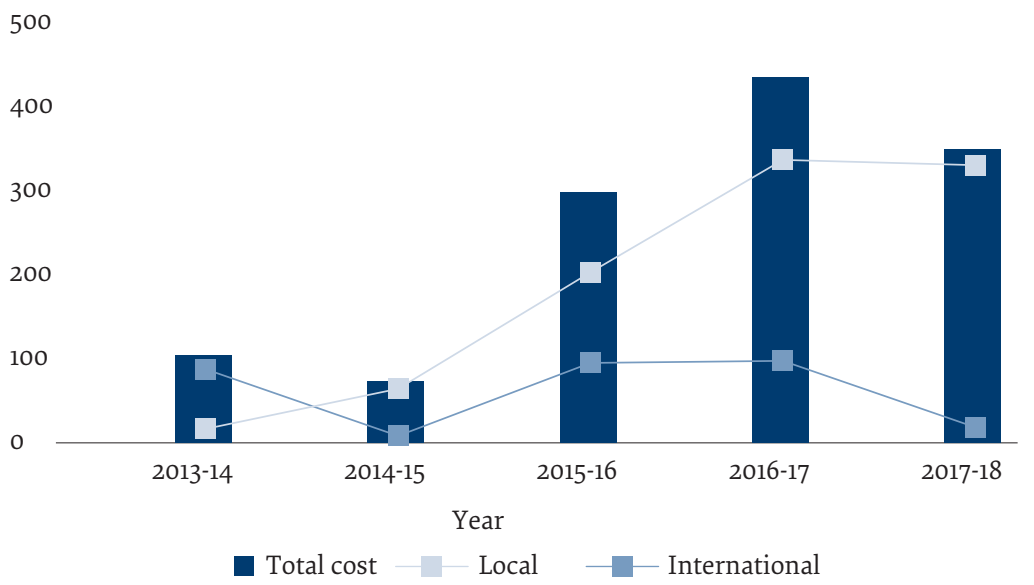

Pakistan is a developing country with a double burden of communicable and noncommunicable diseases, and ranks among the top 10 countries having a high burden of tuberculosis, hepatitis, diabetes, etc. (14). The overall health budget is low and health research is not on the list of priorities. In our study, total spending on health research for the last 5 years was US\$ 1.68 million, about $0.000003 \%$ of GDP (2018) in Pakistan. The health research funding in India was US\$ 1.42 billion, about $0.09 \%$ of GDP (13). The research and development expenditure was $0.68 \%$ of GDP in Egypt, $0.47 \%$ in Qatar and $0.49 \%$ in the United Arab Emirates (15). In the current study, we saw a gradual increase in the number of publications, with a significant rise in articles in Pubmed indexed journals, which has a significant association with health research funding. It has been shown that research output has a direct relation with polices and health research funding (16). It has been reported that Pakistan has contributed $8 \%$ of the PubMed indexed publications made from the countries of the WHO Region for the Eastern Mediterranean. Further comparison of Medline publications in Pakistan gave a value of 1.52 per 100000 population per year, less than
Kuwait (12.5), Tunisia (10.5) and Qatar (9.5), but greater than Syria $(<1)$, Sudan $(<1)$ and Yemen $(<1)(15)$.

In order to reduce the burden of disease and provide quality services to the public, there is a need to generate scientific evidence for proper utilization of the available resources. The current findings are a positive indication for health research in the country but there are potential challenges, including the low priority given to research at government level and consequent poor funding and lack of incentive, resulting in a constant brain drain and absence of a national priority list. Further, there is no uniform funds dispersal system as the Pakistan Health Research Council, Higher Education Commission and Pakistan Science Foundation working in isolation, resulting in duplication and waste of money. Similarly, the majority of international donors have their own priorities for research and only a few of them are actually funding the country's needs-based research.

As is evident, major health research funding is derived from the public sector, thus, the current economic crisis might have a direct impact on health research. The

Figure 2 Number of publications on health research in Pakistan during 2013-2018

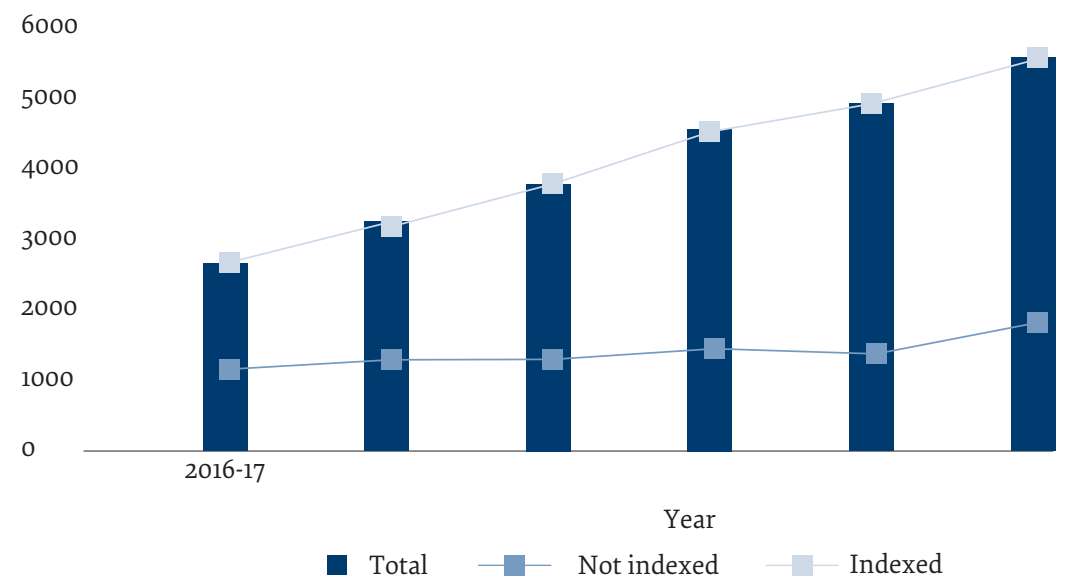


government has already slashed many development projects. There are growing fears of low funding for the Higher Education Commission and other research organizations, ultimately affecting the research output. To maintain the momentum and face the challenge, the mindset needs to change from "research as spending" to "research as investment". The government should enhance funding in research with proper allocation in the budget. Allocated funds should be dispersed through a uniform and coordinated mechanism for rational utilization. The international donors could be sensitized on the key health issues to increase inflow; researchers should also explore international funding opportunities. It will be disastrous for Pakistan if it fails to maintain the momentum of health research in the country.

Although it is mandatory for all institutions to obtain ethical clearance from the National Bioethics Committee for international grants and for those at national level, in some cases the institution may take ethical clearance from the local institutional ethical review board for small scale studies. Therefore, it is possible that information from some of the projects may have been missed and this constitutes a limitation of our study.

\section{Acknowledgment}

We thank Dr Faiza Bashir, Medical Officer/Coordinator, National Bioethics Committee, for providing information on international grants. We are also grateful to Ms Tayyaba Rahat, Statistical Officer, for doing the statistical analysis of the study and Mr Saeed Ahmed Shahid for data entry.

Funding: None.

Competing interests: None declared.

\section{Le financement de la recherche en santé et ses résultats au Pakistan}

\section{Résumé}

Contexte : La recherche en santé est très importante pour élaborer des politiques fondées sur des bases factuelles.

Objectifs : Évaluer le financement de la recherche en santé et ses résultats au cours des cinq derniers exercices fiscaux (de 2013 à 2018) au Pakistan.

Méthodes : Les informations sur le financement de la recherche en santé ont été obtenues auprès de trois grands organismes locaux - la Commission de l'enseignement supérieur, la Fondation pakistanaise des Sciences et le Conseil pakistanais de la recherche en santé. Les données concernant le financement par des donateurs internationaux ont été collectées et le nombre de publications a été estimé à partir de PubMed et PakMediNet.

Résultats : Un total de 1261,6 millions de roupies pakistanaises (8,4 millions de dollars des États-Unis) a été dépensé pour la recherche en santé au cours des cinq derniers exercices fiscaux, provenant en grande partie de donateurs locaux $(p<0,02)$. Le financement global est passé de 104,7 millions de roupies en 2013-2014 à 349,8 millions de roupies en 2017-2018. Dans les données relatives aux publications, 24796 articles originaux ont été publiés, dont 16137 indexés et 8659 non indexés dans Medline. Dans l'ensemble, on constate une augmentation progressive du nombre de publications par an, celle-ci est statistiquement significative pour les revues indexées dans Medline. Le financement de la recherche présentait une forte corrélation (alpha de Cronbach de 0,88) avec les publications.

Conclusion : Le financement de la recherche en santé a une incidence directe sur ses résultats. Il doit être considéré comme un investissement et non comme une dépense.

$$
\begin{aligned}
& \text { تمويل البحوث الصحية ونو الجها في باكستان } \\
& \text { محمد عارف نديم سقيب، إبرار رفيق } \\
& \text { الخالاصة } \\
& \text { الخلفية: للبحوث الصحية أهمية بالغة في صياغة السياسات المُسنَّة بالبيّنات. } \\
& \text { الأهداف: هدفت هذه الدر اسة إلى تقييم تمويل البحوث الصحية ونو اتجها خلال السنوات المالية الخمس الماضية (2013-14 20 حتى 2018) في } \\
& \text { باكستان. }
\end{aligned}
$$

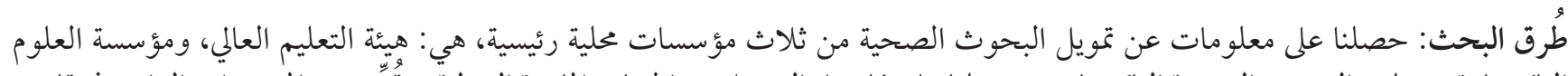

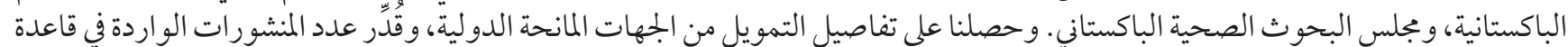

$$
\begin{aligned}
& \text { بيانات PubMed و Pakmedinet }
\end{aligned}
$$


النتائج: أنفق ما بجموعه 1.6126 مليون روبية باكستانية (4.4 مالايين دو لار أمريكي) على البحوث الصحية في السنوات المالية الخمس الماضية،

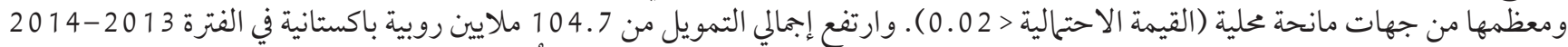

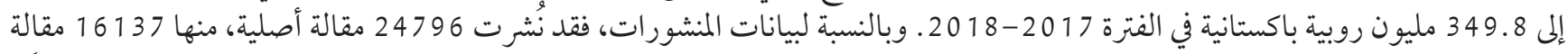

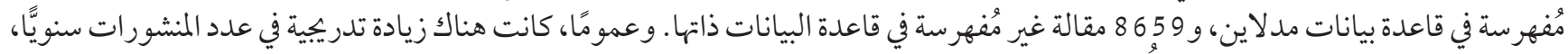

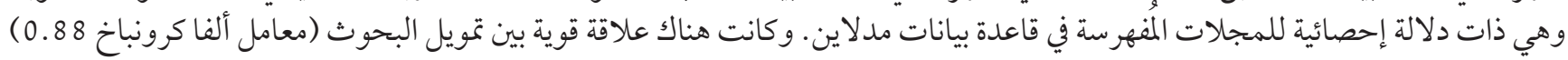
و والمنشورات.

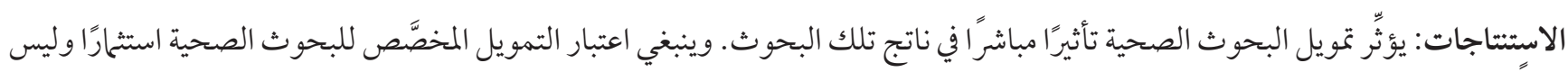
إنفاقًا.

\section{References}

1. Research and development to meet health needs in developing countries: strengthening global financing and coordination. Geneva: World Health Organization, 2012.

2. Research. Geneva: World Health Organization; 2012.

3. Sambo M.doR, Ferreira AV. Current status on health sciences research productivity pertaining to Angola up to 2014. Health Res Policy Syst. 2015 Jul 1;13:32. doi:10.1186/s12961-015-0021-Z

4. Franzen SR, Chandler C, Lang T. Health research capacity development in low and middle income countries: reality or rhetoric? A systematic meta-narrative review of the qualitative literature. BMJ Open. 2017 Jan 27;7(1):e012332. doi:10.1136/bmjopen-2016-012332

5. Soteriades ES, Rosmarakis ES, Paraschakis K, Falagas ME. Research contribution of different world regions in the top 50 biomedical journals (1995-2002). FASEB J. 2006 Jan;20(1):29-34. doi:10.1096/fj.05-4711lsf

6. Global observatory on health R\&D. Geneva: World Health Organization; 2017 (https://www.who.int/research-observatory/en/, accessed 12 April 2021).

7. Sadana R, D'Souza C, Hyder AA, Chowdhury AM. Importance of health research in South Asia. BMJ. 2004 Apr 3;328(7443):82630. doi:10.1136/bmj.328.7443.826

8. Ranasinghe P, Jayawardena R, Katulanda P. Sri Lanka in global medical research: a scientific analysis of the Sri Lankan research output during 2000-2009. BMC Res Notes. 2012 Feb 24;5:121. doi:10.1186/1756-0500-5-121

9. Akhtar T, Khan JA. Health research capacity in Pakistan. A country report prepared for the WHO and COHRED Regional Consultation on Health Research for Development. Cairo 24-26 June 2000 (http://www.cohred.org/downloads/681.pdf, accessed 28 March 2021).

10. Islamabad: National Bioethics Committee. 2021

11. Kalita A, Shinde S, Patel V. Public health research in India in the new millennium: a bibliometric analysis. Glob Health Action. 2015 Aug 14;8:27576. doi:10.3402/gha.v8.27576

12. Ghaffar A, Zaidi S, Qureshi H, Hafeez A. Medical education and research in Pakistan. Lancet. 2013 Jun 29;381(9885):2234-6. doi:10.1016/S0140-6736(13)60146-4

13. Swaminathan S, Qureshi H, Jahan MU, Baskota DK, De Alwis S, Dandona L. Health research priorities and gaps in South Asia. BMJ. 2017 Apr 11;357:j1510. doi:10.1136/bmj.j1510

14. Country cooperation strategy. Geneva: World Health Organization; 2018 (https://apps.who.int/iris/bitstream/handle/10665/136607/ccsbrief_pak_en.pdf?sequence=1, accessed 24 June 2019).

15. Tadmouri GO, Mandil A, Rashidian A. Biomedical and health research geography in the Eastern Mediterranean Region. East Mediterr Health J. 2019 Nov 4;25(10):728-43. doi:10.26719/emhj.19.082

16. Yazdizadeh B, Majdzadeh R, Janani L, Mohtasham F, Nikooee S, Mousavi A, et al. An assessment of health research impact in Iran. Health Res Policy Syst. 2016 Jul 26;14(1):56. doi:10.1186/s12961-016-0129-9 